\title{
PENGEMBANGAN BAHAN AJAR MATEMATIKA BERBASIS NILAI-NILAI ISLAM PADA MATERI ARITMATIKA SOSIAL
}

\author{
Arni Rahmawati ${ }^{1)}$, Swaditya Rizki ${ }^{2)}$ \\ 1,2 Pendidikan Matematika FKIP Universitas Muhammadiyah Metro \\ Email: arnirahmawati1@gmail.com ${ }^{1)}$, swadityarizki@ummetro.ac.id ${ }^{2)}$
}

\begin{abstract}
The objective of this research and development is to develop teaching materials of mathematics on social arithmetic based on Islamic values that are feasible, practical, and effective. This research type is Research and Development $(R \& D)$. The model used in this research is consisting of 10 stages. The instruments of data collection used the questionnaires and evaluation questions. The questionnaires are consisting of design, material, and Islamic content. The result of the research is the average of validation percentage is $82,3 \%$, so the teaching material is categorized as feasible. Based on the validation process showed that the teaching material that developed is included the feasible category, with an average percentage are $82.3 \%$. While the results of small group trial showed that the responses of students in the pilot phase of small groups from 16 students are obtained $87.5 \%$, and the result from the test is obtained the average more than $75 \%$ of the students who score more than the standard of 75.00. From the results of this research can be concluded that the teaching material of social arithmetic is feasible, practical, and effective.
\end{abstract}

Keywords: islamic values, mathematics, $R \& D$, social arithmetic, teaching materials

\section{PENDAHULUAN}

Pendidikan adalah pintu utama seseorang untuk menuju perubahan dirinya, berubah menjadi lebih baik atau sebaliknya. Dalam kurikulum 2013 bahwa pengetahuan bukan aspek utama, ada aspek ketrampilan dan sikap yang harus tercapai, seperti aspek sikap yang meliputi sopan santun, adap dalam belajar, absensi sosial, dan agama. Menurut Tafsir (2011:12) "ilmu pendidikan islam adalah ilmu pendidikan yang berdasarkan islam. Islam berisi seperangkat ajaran tentang kehidupan manusia, ajaran itu dirumuskan berdasarkan dan bersumber pada Al-Qur'an dan hadits serta akal".

Guru tidak hanya mementingkan penyampaian aspek pengetahuan kepada peserta didiknya saat proses pembelajaran, tetapi aspek sikap dan ketrampilan juga penting untuk mencapai makna pembelajaran. Sedangkan makna dari pembelajaran adalah suatu proses yang diupayakan agar peserta didik dapat mengoptimalkan potensi yang dimiliki baik kognitif maupun sosio emosional secara efektif dan efesien untuk mencapai perubahan perilaku yang diharapkan.

Permasalahan yang terdapat di MTs Al Muhsin sehingga perlu dikembangkannya bahan ajar matematika berbasis nilai-nilai islam diantaranya adalah banyak peserta didik yang tidak suka dengan pelajaran umum seperti matematika, karena kebanyakan peserta didik lebih menyukai pelajaran agama. Peserta didik merasa pelajaran matematika sulit, karena banyaknya rumus yang sulit untuk dimengerti, dan MTs Al Muhsin adalah sekolah yang berbasis keislaman tetapi dalam proses 
pembelajaran umum seperti matematika belum dikaitkan dengan nilai-nilai islam karena tidak adanya bahan ajar yang menunjang permasalahan tersebut. Hal ini sesuai dengan pendapat Soleha dan Rada (2011:8) menyatakan bahwa ilmu pendidikan islam khususnya yang bersumberkan nilai-nilai agama islam disamping menanamkan dan membentuk sikap hidup yang dijiwai nilai-nilai tersebut, juga mengembangkan kemampuan berilmu pengetahuan sejalan dengan nilai-nilai islam yang melandasi adalah merupakan proses ikhtiar yang secara pedagogis mampu mengembangkan hidup anak didik kearah kedewasaan atau kematangan yang menguntungkan dirinya.

Selanjutnya pendidikan islam dibagi menjadi dua seperti pendapat Qomar (2013:3) menyatakan bahwa pendidikan islam dapat dibagi menjadi tiga yaitu pertama, pendidikan islam yang berbentuk ide-ide, gagasangagasan, pemikiran-pemikiran, wawasan, konsep, dan teori. Kedua, pendidikan islam yang berbentuk penyelenggaraan, pelaksanaan,atau penerapan secara kelembagaan. Ketiga, pendidikan islam yang berbentuk perilaku umat islam dalam meresponnya.

Dalam hal ini nilai-nilai islam yang diintegrasikan dalam pelajaran matematika akan membantu perkembangan peserta didik menjadi lebih baik. Seperti pendapat Kurniati (2015:2) bahwa matematika sebaiknya diperkenalkan dan diajarkan kepada anak dengan cara-cara yang menarik dan dengan memadukan dan menyelaraskan materi matematika dengan nilai keislaman. Memadukan matematika dengan nilai keislaman akan terbentuk bangsa yang tangguh, berorientasi ilmu pengetahuan dan teknologi yang semuanya dijiwai oleh iman dan takwa kepada Allah SWT. Dalam pembelajaran matematika sangat penting untuk membentuk pribadi yang berkualitas. Jika dapat mengintregasikan islam dari setiap konsep matematika tentunya akan lebih mudah mengembangkannya dalam setiap proses pembelajaran.

Nilai islam yaitu sebagai konsep dan keyakinan seperti pendapat Callie (2014:44) menyatakan bahwa nilai-nilai islam yaitu sebagai konsep dan keyakinan yang dijunjung tinggi oleh manusia mengenai beberapa masalah pokok yang berhubungan dengan islam untuk dijadikan pedoman dalam bertingkah laku, baik nilai bersumber dari Allah maupun hasil interaksi manusia tanpa bartentangan dengan syariat.

Berdasarkan beberapa pendapat diatas dapat disimpulkan bahwa nilainilai islam adalah sifat-sifat atau dasar keimanan, kepribadian, serta budi pekerti yang baik yang dibingkai dalam aturan islam untuk memperbaiki akhlak dan perilaku manusia.

Bahan ajar matematika berbasis nilai-nilai islam merupakan salah satu media untuk mengatasi permasalahan tersebut, agar peserta didik tidak hanya berpikir bahwa matematika itu banyak angka dan rumus saja tetapi juga ada nilai-nilai islam yang terkandung didalamnya. Bahan ajar yang dikembangkan membahas jual beli diantaranya yang berkaitan dengan riba dan pengambilan untung. Hal ini diharapkan menjadikan pembelajaran matematika akan menjadi lebih bermakna dan dapat diterapkan dalam kehidupan peserta didik. Seperti pendapat Trianto (2011:188) menyatakan bahwa "bahan ajar adalah bahan atau material atau sumber belajar yang mengandung substansi kemampuan tertentu yang akan dicapai oleh siswa". 
Tujuan dalam pengembangan ini adalah menghasilkan produk berupa bahan ajar matematika berbasis nilainilai islam pada materi aritmatika sosial yang layak, praktis dan efektif digunakan sebagai sumber belajar untuk Siswa MTs Al Muhsin Kelas VII.

Pembelajaran matematika dengan menanamkan nilai-nilai islam mempunyai keunggulan yakni pembelajaran didasari dengan pengetahuan keislaman. Pendidikan matematika yang mengandung nilainilai islam menempatkan matematika sebagai jalan bagi peserta didik untuk memperbaiki moral peserta didik. Dalam pembelajaran matematika pengetahuan peserta didik tidak hanya pada konsep matematika atau rumusrumus matematika tetapi, mengaitkan pembelajaran dengan kehidupan seharihari yang didasari dengan nilai-nilai islam. Maka dari itu dengan menggunakan bahan ajar matematika berbasis nilai-nilai islam dapat menjadi solusi peserta didik untuk belajar matematika dengan kandungan nilainilai islam tidak hanya tentang rumus dan soal saja yang membosankan tetapi juga memperoleh pengetahuan keislaman dari belajar materi aritmatika sosial.

\section{METODE PENELITIAN}

Penelitian dan pengembangan yang dilakukan untuk menghasilkan suatu produk yang baik dalam arti sesuai dengan kriteria-kriteria yang telah ditetapkan, maka pembuatan produk berupa bahan ajar harus dilakukan secara sistematis, melalui prosedur yang benar dan sesuai kaedahkaedah yang baik. Dengan berbagai pertimbangan maka dalam penelitian dan pengembangan ini dipilih model pengembangan dengan langkah-langkah menurut Sugiyono (2014:409), sebagaimana yang dijelaskan bahwa menurut Sugiyono (2014:407), penelitian dan pengembangan (R\&D) adalah "metode penelitian yang digunakan untuk menghasilkan produk tertentu, dan menguji keefektifan produk tersebut". Penelitian dan pengembangan akan menghasilkan produk baru untuk menyempurnakan produk sebelumnya.

Penelitian dan pengembangan ini menggunakan model pengembangan yang dijelaskan pada langkah-langkah dalam melakukan pengembangan menurut Sugiyono (2014:409) langkahlangkah penelitian dan pengembangan yang telah diadaptasi ditunjukkan pada Gambar 1 berikut.

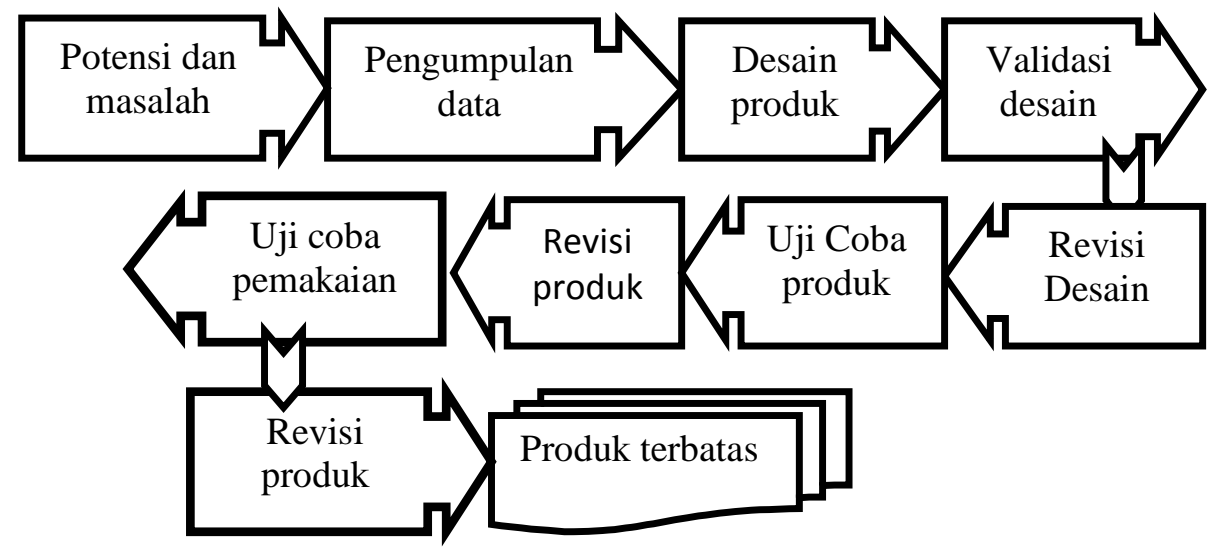

Gambar 1. Langkah langkah Penggunaan Metode Research and Development (R\&D). Sugiyono (2014:409) 
Ada tiga macam instrumen validasi yang akan digunakan yaitu lembar validasi ahli desain, ahli keislaman, dan ahli materi. Validasi desain ini diuji oleh tim ahli yang terdiri dari validator 1 adalah ahli desain yaitu dosen matematika, validator 2 adalah ahli keislaman yaitu dosen Pendidikan Agama Islam, validator 3 adalah ahli materi yaitu guru SMP Muhammadiyah 3 Metro, validator 4 adalah ahli materi yaitu guru MTs Al Muhsin. Uji kelayakan ini dilakukan sebelum produk diujicobakan pada peserta didik. Setelah desain bahan ajar divalidasi dan masih ada kekurangan maka akan direvisi kembali dan divalidasi lagi. Namun apabila desain sudah layak dan tidak perlu direvisi kembali maka desain sudah bisa langsung diujicobakan.

Uji produk ini dilakukan setelah bahan ajar telah divalidasi oleh ahli dan uji produk ini dilakukan agar dapat diketahui tanggapan dari objek pengembangan bahan ajar tersebut. Uji produk ini dilakukan pada responden dalam kelompok kecil atau uji terbatas pada enam belas orang peserta didik (bukan objek penelitian) kelas VII MTs Al Muhsin Metro. Pengujian pada kelompok kecil ini yaitu peserta didik diberikan bahan ajar yang telah diuji kelayakannnya serta diberi angket respon peserta didik. Hal ini dilakukan agar bahan ajar yang dikembangkan bisa diketahui kepraktisannya oleh peserta didik pada kelompok kecil. Dalam uji produk ini peserta didik diberi bahan ajar kemudian diberikan angket lembar komentar, tujannya agar dapat mengetahui kepraktisan bahan ajar yang dikembangkan menurut pandangan peserta didik tersebut.

Uji coba pemakaian ini dilakukan setelah produk diujicobakan dalam kelompok kecil dan telah direvisi dari hasil komentar peserta didik dalam kelompok kecil, dalam uji coba pemakaian produk yang berupa bahan ajar matematika digunakan peserta didik kelas VIIB yang berjumlah 27 peserta didik sebagai vasilitas dalam belajar pada materi aritmatika sosial untuk diketahui keefektifan dari produk tersebut. Kefeektifan dilihat dari hasil KKM peserta didik setelah memakai bahan ajar dalam 4 kali pertemuan dan diberikan soal evaluasi.

Teknik analisis data yang dilakukan yaitu analisis validasi produk untuk mengetahui kelayakan produk dengan persentase nilai lebih dari $60 \%$, kemudian analisis kepraktisan produk dengan persentase nilai lebih dari $60 \%$, dan terakhir analisis efektivitas produk jika lebih dari $75 \%$ siswa memenuhi nilai kriteria ketuntasan minimal (KKM) yaitu > 75,00.

\section{HASIL PENELITIAN DAN PEMBAHASAN}

Data diperoleh dari hasil validasi terhadap bahan ajar yang dilakukan oleh 4 validator yang terdiri dari 2 dosen UM Metro dan 2 guru. Validator 1 adalah ahli desain yaitu dosen matematika Rina Agustina, M.Pd, validator 2 adalah ahli keislaman yaitu dosen Pendidikan Agama Islam Samson Fajar, S.Sos. I, validator 3 adalah ahli materi yaitu guru SMP Muhammadiyah 3 Metro Ratna Gusmita, S.Pd, validator 4 adalah ahli materi yaitu guru MTs Al Muhsin Nur Azizah, S.Pd.

Data rata-rata persentase dari keempat validator yang merupakan tolak ukur tingkat kelayakan bahan ajar disajikan dalam Tabel 1 berikut: 
ISSN 2089-8703 (Print) Vol. 6, No. 1 (2017)

ISSN 2442-5419 (Online)

Tabel 1. Rata-rata Persentase Tingkat Kelayakan Bahan Ajar

\begin{tabular}{|c|c|c|}
\hline Validator & Persentase & Kategori \\
\hline VI & $83 \%$ & Sangat Layak \\
\hline V2 & $87 \%$ & Sangat Layak \\
\hline V3 \& V4 & $77 \%$ & Layak \\
\hline Rata-rata & $82,3 \%$ & Sangat Layak \\
\hline
\end{tabular}

Keterangan: V1:ahli desain, V2: ahli keislaman, V3: ahli materi 1, V4: ahli materi 2

Hasil penilaian dari keempat validator ahli yaitu ahli desain, ahli keislaman, dan dua ahli materi terhadap bahan ajar secara umum sudah baik tetapi perlu ada revisi, setelah dilakukan revisi dari masing-masing komentar validator, maka bahan ajar tersebut diajukan kembali untuk persetujuan kevalidannya kemudian diujicobakan. Adapun diagram hasil validasi bahan ajar disajikan pada Gambar 2 sebagai berikut:

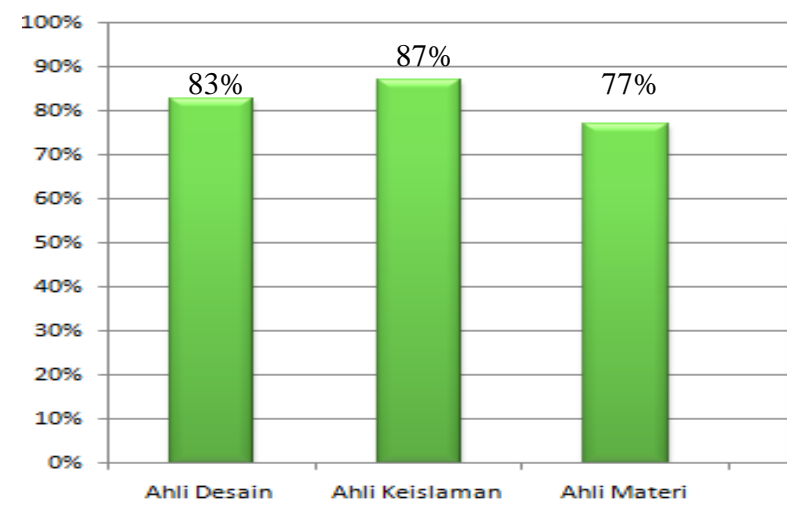

Gambar 2. Grafik Hasil Penilaian Validator

Selanjutnya hasil uji coba pada kelompok kecil yang terdiri dari 6 peserta didik yaitu berupa data dan 10 peserta didik berupa komentar. Uji coba bahan ajar kelompok kecil yaitu ada dua tahap yaitu pada 6 peserta didik untuk angket yang berupa skala dan 10 peserta didik untuk angket berupa komentar, setelah peserta didik diberikan bahan ajar yang telah dikembangkan selanjutnya peserta didik diberikan angket penilaian bahan ajar yang berisi pernyataan-pernyataan tentang bahan ajar.
Analisis rata-rata jawaban peserta didik adalah sebagai berikut:

$$
=\frac{735}{840} \times 100 \%=87,5 \% \approx \text { Sangat Setuju }
$$

Selanjutnya analisis berdasarkan komentar yang menyebutkan kesetujuan atau tidak terhadap pernyataan yang disajikan dalam angket. Peserta didik yang berjumlah 10 memberikan komentar yang menyatakan kesetujuan dengan pernyataan yang terdapat dalam angket berarti komentar tersebut dinyatakan setuju, sedangkan untuk komentar yang menyatakan tidak setuju 
artinya peserta didik memberikan komentar kurang atau tidak sesuai dengan pernyataan yang ada dalam angket. Berdasarkan rata-rata nilai tersebut artinya bahan ajar yang diujicoba termasuk dalam kategori sangat praktis.

Hasil uji coba pemakaian yang berupa nilai evaluasi, yang telah diuji cobakan pada 27 peserta didik kelas VIIB MTs Al Muhsin. Uji coba pemakaian ini memperoleh hasil berupa nilai tes, peserta didik yang berjumlah 27 peserta didik telah tuntas (memenuhi KKM). Berdasarkan hasil yang didapat dianalisis bahwa $75 \%$ lebih peserta didik sudah memenuhi KKM yang ditetapkan yaitu 75,00 maka dapat disimpulkan bahwa bahan ajar efektif digunakan dalam kegiatan pembelajaran matematika.

Berdasarkan hasil dari penelitian dan pengembangan yang diperoleh dapat disimpulkan bahwa bahan ajar yang telah divalidasi oleh para ahli, dan diuji cobakan yaitu uji coba kelompok kecil dengan penilaian angket dan uji coba pemakaian dengan soal evaluasi kepada peserta didik telah dilakukan revisi. Revisi tersebut sesuai komentar atau saran yang diberikan oleh validator dan peserta didik yang telah dinyatakan layak karena telah teruji kevalidannya oleh validator, praktis karena telah di uji coba pada kelompok kecil hingga memenuhi kriteria praktis, dan efektif karena telah di uji coba pemakaian dan semua peserta didik dinyatakan tuntas dalam tes evaluasi, sehingga bahan ajar matematika berbasis nilai-nilai islam dapat digunakan dalam kegiatan pembelajaran matematika.

$\begin{array}{ccr}\text { Seperti } & \text { pendapat } & \text { Suparman } \\ (2012: 282) & \text { menyatakan } & \text { bahwa }\end{array}$
"Pengembangan meliputi menyusun, melaksanakan, dan mengevaluasi bahan yang dikembangkan". Dari hasil pengembangan bahan ajar yang mengikuti

langkah-langkah pengembangan model Sugiyono (2014:409), bahwa semua langkah telah dilakukan dan mendapatkan hasil. Hasil dari pengembangan adalah bahan ajar berupa modul dengan rancangan yang telah dibuat. Sedangkan Asyhar (2011:163) manyatakan bahwa modul adalah salah satu bentuk bahan ajar berbasis cetakan yang dirancang untuk belajar secara mandiri oleh peserta pembelajaran kerena itu modul dilengkapi dengan petunjuk untuk belajar sendiri. Isi bahan ajar meliputi uraian mengenai topik-topik utama, konsep, dan prinsip. Isi bahan ajar dapat diidentifikasi baik berdasarkan pendekatan yang berorientasi pada subyek pengajaran maupun pendekatan yang berorientasi pada peserta belajar.

Bahan ajar yang dikembangkan berbasis nilai-nilai islam dengan materi aritmatika sosial yang membahas tentang jual beli. Seperti pendapat Aziz dan Setyono (2013:13) menyatakan bahwa aritmatika sosial meliputi untung yaitu laba yang diperoleh dalam sebuah transaksi, rugi yang artinya kurang dari modal, karena menjual lebih rendah dari harga pokok, diskon atau rabat yaitu potongan harga dalam suatu transaksi, bruto yaitu berat kotor, netto yaitu berat bersih, berat pembungkus/kaleng/karung, bunga tabungan yaitu imbalan jasa untuk penggunaan uang atau modal yang dibayar pada waktu yang disetujuai, dan pajak yaitu pungutan wajib barupa uang yang harus dibayar oleh penduduk sebagai sumbangan wajib kepada negara atau pemerintah sehubungan dengan pendapatan pemilikan, harga beli barang, dan sebagainya. Berdasarkan pendapat tersebut maka bahan ajar matematika yang membahas tentang jual beli, bunga, dan pajak disajikan dengan pengetahuan keislaman untuk menambah wawasan 
peserta didik dan nantinya bisa diterapkan dalam kehudupan seharihari.

Berdasarkan komentar dan saran yang diberikan oleh validator pada lembar validasi, maka rancangan awal bahan ajar dilakukan revisi berdasarkan komentar dan saran yang diberikan oleh validator tersebut. Setelah revisi dilakukan maka bahan ajar diajukan kembali untuk persetujuan telah dilakukan revisi kepada validator dan bahan ajar dinyatakan layak untuk diuji cobakan kepada peserta didik. Kemudian setelah direvisi dan dinyatakan layak maka bahan ajar diuji cobakan pada kelompok kecil yaitu 6 peserta didik mengisi angket berupa skala angka dan 10 peserta didik mengisi angket berupa komentar untuk dinilai kepraktisannya. Maka dari hasil uji coba kelompok kecil bahan ajar dinyatakan praktis.

Selanjutnya bahan ajar diuji coba pemakaian selama 4 kali pertemuan dan peserta didik diberikan soal tes evaluasi untuk mengetahui keefektifan bahan ajar yang dikembangakan, yaitu dilihat dari nilai masing-masing peserta didik yang lebih dari KKM yang ditetapkan 75,00 maka bahan ajar dinyatakan efektif. Berdasarkan nilai yang didapat peserta didik sudah lebih dari $75 \%$ memenuhi KKM yang ditetapkan yakni 75,00 maka bahan ajar yang dikembangkan sudah efektif.

Dari hasil tersebut bahwa bahan ajar matematika berbasis nilai-nilai Islam pada materi aritmatika sosial tersebut baik untuk digunakan dalam proses pembelajaran. Dalam hal ini, pengembangan bahan ajar matematika perlu terus dilakukan karena akan menambah variasi dan pengembangan sebagai sumber belajar matematika. Seperti penelitian yang telah dilakukan oleh Rizki dan Linuhung (2016), Mayani dan Rizki (2016), Purwanto dan
Rizki (2015) yang telah mengembangkan bahan ajar matematika dengan variasi yang berbeda-beda untuk perkembangan matematika. Oleh karena itu, pengembangan dan inovasi dalam matematika sangat diperlukan untuk mempermudah siswa dalam memahami matematika.

\section{KESIMPULAN DAN SARAN}

Langkah-langkah penyusunan dalam penelitian dan pengembangan bahan ajar meliputi: potensi dan masalah, pengumpulan data desain produk, validasi desain, revisi desain, uji coba produk, revisi produk, uji coba pemakaian, revisi produk, produksi terbatas. Pengembangan bahan ajar matematika berbasis nilai-nilai islam ini memfasilitasi peserta didik untuk memahami nilai-nilai islam yang terkandung pada materi aritmatika sosial, sehingga peserta didik diharapkan bisa menerapkan dalam kehidupan setelah mengetahui dan mempelajari materi tersebut.

Kelebihan bahan ajar yang dikembangkan adalah mempunyai kandungan nilai-nilai islam dan materi keislaman dijabarkan sesuai materi matematika aritmatika sosial yang ada, seperti dalam aritmatika sosial terdapat pembahasan jual beli maka dijelaskan jual beli dalam islam. Kemudian kelemahan bahan ajar yang dikembangkan adalah pembahasan soalsoal belum sepenuhnya tertuju pada nilai islam, kebanyakan nilai islam yang terkandung dijelaskan berdasarkan materi yang ada pada aritmatika sosial.

Dapat dinyatakan bahwa bahan ajar matematika berbasis nilai-nilai islam materi aritmatika sosial mampu berkontribusi dalam mengembangan pengetahuan peserta didik dari segi keislaman dan dapat diterapkan dalam kehidupan sehari-hari. Untuk itu bahan ajar matematika berbasis nilai-nilai 
islam ini dapat digunakan dalam kegiatan pembelajaran dan dapat menambah wawasan peserta didik. Dari hasil penelitian dan pengembangan yang telah dilakukan maka dapat disimpulkan bahwa bahan ajar matematika berbasis nilai-nilai islam pada materi aritmatika sosial dinyatakan layak, praktis dan efektif.

Berdasarkan penelitian dan pengembangan yang telah dilakukan maka ada beberapa saran yaitu pertama, bahan ajar diujicobakan kembali di beberapa sekolah lainnya untuk mendapat hasil yang lebih beragam sehingga penggunaan bahan ajar matematika berbasis nilai-nilai islam nantinya mencapai tujuan yang diharapkan yaitu dapat menanamkan nilai-nilai keislaman dalam diri peserta didik. Kedua, Bahan ajar matematika berbasis nilai-nilai islam pada materi aritmatika sosial untuk siswa MTs kelas VII ini dapat digunakan, dikembangkan dan diperbaiki lebih lanjut untuk digunakan pada kegiatan penelitian pengembangan selanjutnya. Ketiga, Materi dan latihan soal dapat dikembangkan lagi pada permasalahan yang lain dalam aritmatika sosial untuk memperkaya pemahaman.

\section{DAFTAR PUSTAKA}

Asyhar, R. 2011. Kreatif Mengembangkan Media Pembelajaran. Jakarta: Gaung Persada.

Aziz, A dan Setyono,B. 2013. Menguasai Matematika SMP. Jakarta: Kawah Media.

Callie. 2014. Nilai-nilai Keislaman. Jakarta: Ufuk Press.

Kurniati, A. 2015. Mengenalkan Matematika Terintegrasi Islam Kepada Anak Sejak Dini. Suska Journal of Mathematics Education Vol.1, No.1, 2015. ISSN 2477-4758. Pendidikan
Matematika UIN Sultan Syarif Kasim Riau.

Mayani, S. dan Rizki, S. 2016. Pengembangan Bahan Ajar Berbasis Pendidikan Matematika Realistik (PMR) Pada Materi Program Linear. AKSIOMA Jurnal Pendidikan Matematika, Volume 5. No.1, hal 25-39. Universitas Muhammadiyah Metro

Purwanto, Y. dan Rizki, S. 2015. Pengembangan Bahan Ajar Berbasis Kontekstual Pada Materi Himpunan Berbantu Video Pembelajaran. AKSIOMA Jurnal Pendidikan Matematika, Volume 4. No.1, hal 67-77. Universitas Muhammadiyah Metro

Qomar, M. 2013. Strategi Pendidikan Islam. Jakarta: Erlangga.

Rizki, S. dan Linuhung, N. 2016. Pengembangan Bahan Ajar Program Linear Berbasis Kontekstual dan ICT. AKSIOMA Jurnal Pendidikan Matematika, Volume 5. No.2, hal 137-144. Universitas Muhammadiyah Metro

Soleha dan Rada. 2011. Ilmu Pendidikan Islam. Bandung: Alfabeta.

Sugiyono. 2014. Metode Penelitian Pendidikan (Kuantitatif, Kualitatif, dan $R \& D)$. Bandung: Alfabeta.

Suparman, A. 2012. Desain Intruksional Modern. Jakarta: Erlangga.

Tafsir, A. 2011. Ilmu Pendidikan Dalam Perspektif Islam. Bandung: Remaja Rosdakarya.

Trianto. 2011. Mendesain Model Pembelajaran InovatifProgresif. Jakarta: Kencana Prenada Media Group. 